\title{
COMPLETE
}

ENGINEERING CHANGE NOTICE

1. ECN

Proi

\begin{tabular}{|c|c|c|c|c|c|c|}
\hline \multirow{3}{*}{$\begin{array}{l}\text { 2. ECN Category } \\
\text { (mark one) } \\
\text { Supplemental } \\
\text { Direct Revision } \\
\text { Change ECN } \\
\text { Temporary } \\
\text { Standby } \\
\text { Supersedure } \\
\text { Cancel/Noid }\end{array}$} & \multirow{3}{*}{$\begin{array}{r}{[]} \\
{[\mathrm{X}]} \\
{[]} \\
{[]} \\
{[]} \\
{[]} \\
{[]}\end{array}$} & \multicolumn{2}{|c|}{$\begin{array}{l}\text { 3. Originator's Nane, Organization, MSIN, } \\
\text { and Telephone No. } \\
\text { Clarence Homi, Data Assessment } \\
\text { and Interpretation, R2-12, } 373 \text { - } \\
1097\end{array}$} & \multicolumn{2}{|c|}{$\begin{array}{l}\text { 3a. USe Required? } \\
{[] \text { Yes }[X] \text { No }}\end{array}$} & $\begin{array}{l}\text { 4. Date } \\
05 / 08 / 96\end{array}$ \\
\hline & & \multicolumn{2}{|c|}{$\begin{array}{l}\text { 5. Project Title/No./Work Order No. } \\
\text { Tank 241-C-102 }\end{array}$} & \multicolumn{2}{|c|}{$\begin{array}{l}\text { 6. Bldg./Sys./Fac. No. } \\
241-\mathrm{C}-102\end{array}$} & $\begin{array}{l}\text { 7. Approval Designator } \\
N / A\end{array}$ \\
\hline & & \multicolumn{2}{|c|}{$\begin{array}{l}\text { 8. Document Numbers Changed by this ECN } \\
\text { (includes sheet no. and rev.) } \\
\text { WHC-SD-WM-TP-206, Rev. } 1\end{array}$} & \multicolumn{2}{|c|}{$\begin{array}{l}\text { 9. Related ECN No(s). } \\
\qquad \text { ECN-625718 }\end{array}$} & $\begin{array}{l}\text { 10. Related PO No. } \\
\qquad N / A\end{array}$ \\
\hline \multirow{2}{*}{\multicolumn{2}{|c|}{$\begin{array}{l}\text { 11a. Modification Work } \\
\text { [] Yes (fill out Btk. } \\
\text { 11b) } \\
{[X] \text { No (NA } 81 k s, 11 b \text {, }} \\
11 c, 11 d \text { ) }\end{array}$}} & \multirow{2}{*}{$\begin{array}{l}\text { 11b. Work Package } \\
\text { No. } \\
\text { N/A }\end{array}$} & \multicolumn{2}{|c|}{$\begin{array}{l}\text { 11c. Modification Work Complete } \\
\text { N/A }\end{array}$} & \multicolumn{2}{|c|}{$\begin{array}{l}\text { 11d. Restored to Original Condi- } \\
\text { tion (Temp. or Standby ECN onty) } \\
\text { N/A }\end{array}$} \\
\hline & & & \multicolumn{2}{|c|}{ Cog. Engineer Signature \& Date } & \multicolumn{2}{|c|}{ Cog. Engineer signature \& Date } \\
\hline
\end{tabular}

12. Description of change

Complete revision.

13a. Justification (mark one)
$\begin{array}{llllllll}\text { Criteria Change } & {[X]} & \text { Design Improvement } & {[]} & \text { Environmental } & \text { [] } & \text { Facility Deactivation } \\ \text { As-Found } & {[]} & \text { Facilitate Const } & {[]} & \text { Const. Error/Omission } & {[]} & \text { Design Error/Omission } & \text { [] }\end{array}$

13b. Justification Details

Changed to comply with new template and DOE-RL recommended modifications.

14. Distribution (include name, MSIN, and no. of copies)

See attached distribution. 


\section{Page 2 of 2} Page 2 of 2 ECN-631551

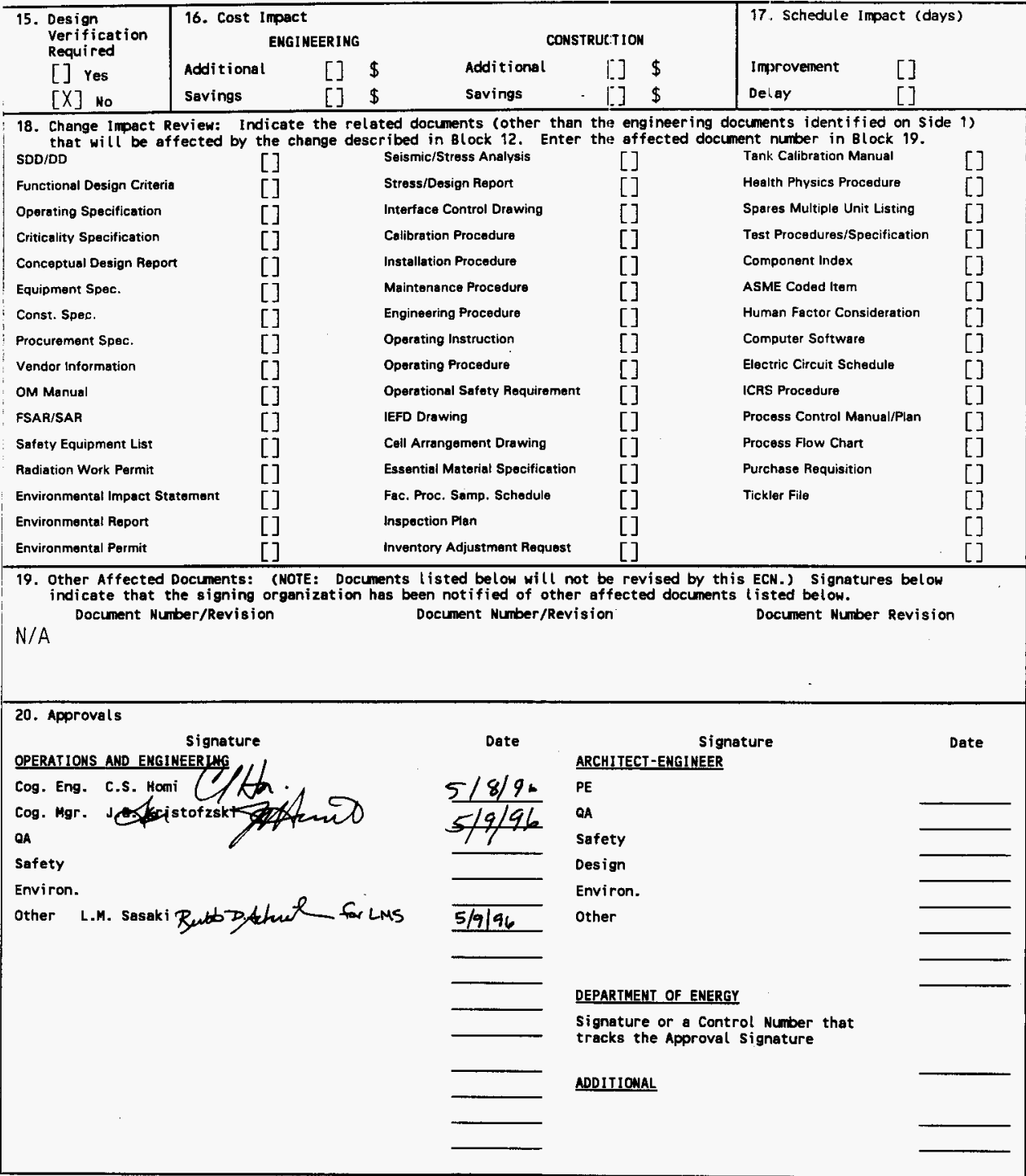




\section{Tank 241-C-102 Tank Characterization Plan}

\section{S. Homi}

Westinghouse Hanford Company, Richland, WA 99352

U.S. Department of Energy Contract DE-AC06-87RL10930

$\begin{array}{lll}\text { EDT/ECN: } & \text { ECN-631551 } & \text { UC: } 2070 \\ \text { Org Code: } 79200 & \text { Charge Code: N4G6A } \\ \text { B\&R Code: } & \text { EW } 3120074 & \text { Total Pages: } 9\end{array}$

Key Words: Characterization, General Safety Issues, Specific Safety Issues, Information Requirements. Schedule

Abstract: This document is a plan that identifies the information needed to address relevant issues concerning short-term and long-term storage and long-term management of single-shell tank 241-C-102.

TRADEMARK DISCLAIMER. Reference herein to any specific comercial product, process, or service by trade name, trademark, manufacturer, or otherwise, does not necessarily constitute or imply its endorsentent, recommendation, or favoring by the United States Government or any agency thereof or its contractors or subcontractors.

Printed in the United states of Anerica. To obtain copies of this document, contact: WHC/BCS Document Control Services, P.O. Box 1970, Mailstop H6-08, Richland WA 99352, Phone (509) 372-2420; fax (509) 376-4989.
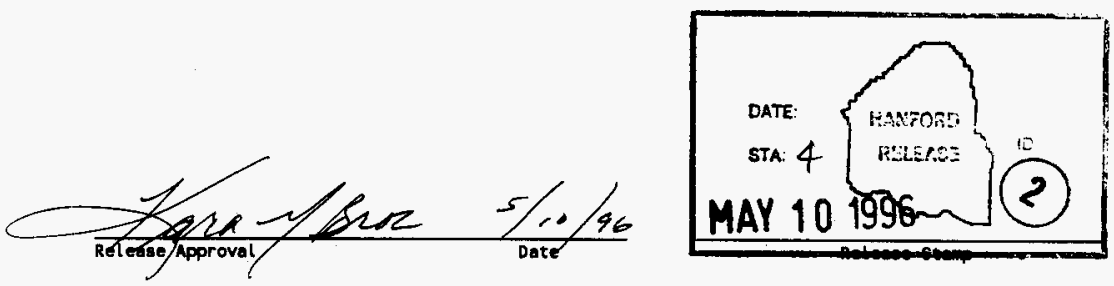


\section{RECORD OF REVISION}

(2) Title

TANK 241-C-102 TANK CHARACTERIZATION PLAN

CHANGE CONTROL RECORD

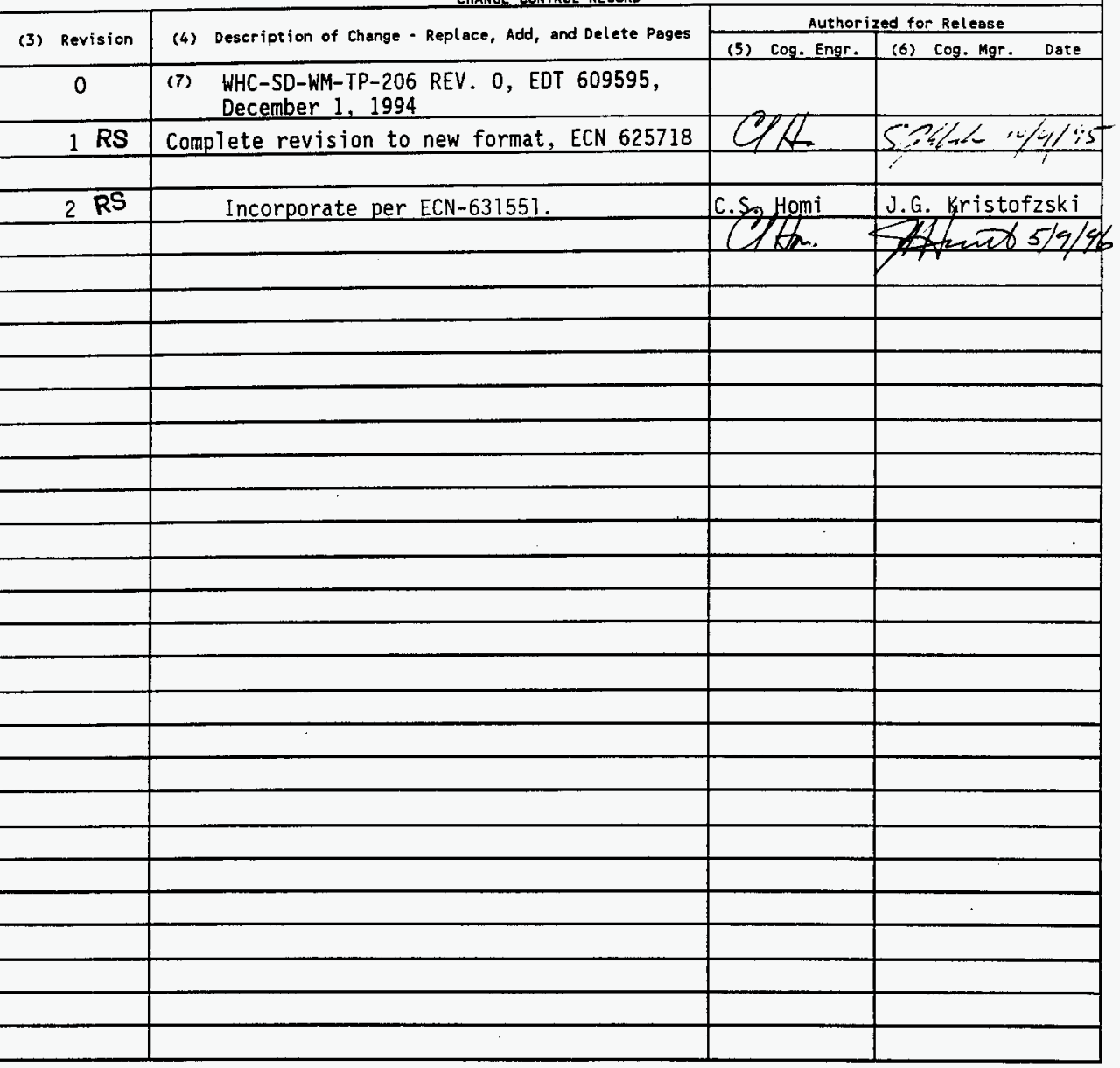


WHC-SD-WM-TP-206

Revision 2

UC-2070

\section{Tank 241-C-102 \\ Tank Characterization Plan}

L. M. Sasaki

Westinghouse Hanford Company

Date Published

May 1996
Prepared for the U.S. Department of Energy

Office of Environmental Restoration and

Waste Management

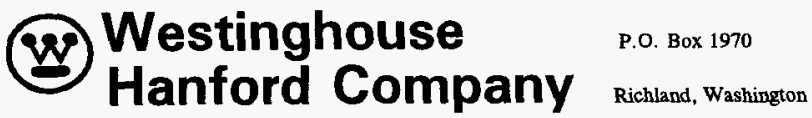

Management and Operations Contractor for the

U.S. Department of Energy under Contract DE-AC06-87RL10930

Approved for Public Release 
WHC-SD-WM-TP-206, REV 2

TABLE OF CONTENTS

1.0 INTRODUCTION . . . . . . . . . . . . . . . . . . . . 1

2.0 PROGRAM ELEMENTS REQUIRING INFORMATION FOR TANK 241-C-102 . . . . . . 2

2.1 GENERAL SAFETY ISSUES ............... 2

2.2 SPECIFIC SAFETY ISSUES ................ 2

2.2.1 Ferrocyanide .............. 2

2.2.2 Organic ................. 2

2.2 .3 High Heat ................. . . 2

2.2.4 Flammable Gas ................. . . 2

2.2 .5 Vapor ................. . . 2

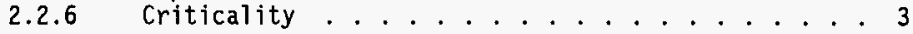

2.3 CONTINUING OPERATIONS .............. 3

2.3.1 Compatibility/Stabilization ........ 3

2.3.2 Evaporator .............. 3

2.4 DOUBLE-SHELL TANK WASTE ANALYSIS PLAN ......... 3

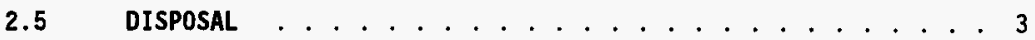

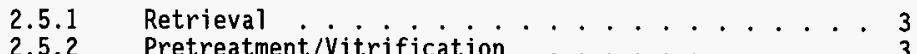

2.6 HISTORICAL MOdEL EVALUATION ............. 4

3.0 HOW INFORMATION WILL BE OBTAINED .............. 4

4.0 PRIORITY OF INFORMATION REQUIREMENTS . . . . . . . . . . . 4

5.0 WHEN INFORMATION WILL BE AVAILABLE ........... 5

6.0 REFERENCES .................... 5

\section{LIST OF TABLES}

4-1 Integrated DQO Requirements and Priorities ............ 4 


\subsection{INTRODUCTION}

This Tank Characterization Plan (TCP) identifies the information needed to address relevant issues concerning short-term and long-term safe storage and long-term management of single-shell tank 241-C-102 (C-102). It should be understood that the various needs and issues surrounding tank C-102 are evolving as new information about the tank is uncovered. As a result of this progression, this TCP addresses only the issues that, to this date, have been identified. It is expected that deviations from this plan may occur as additional issues or needs arise which impact the management of tank C-102. As necessary, this TCP will be revised to reflect those changes or deviations. This plan reflects the best information available as of May 1996.

Tank C-102 was constructed between 1943 and 1944 and was put into service in May 1946 (Brevick et al. 1995). Tank C-102 received metal waste from the cascade overflow of tank 241-C-101 beginning in May 1946. Tank C-102 contained metal waste from the second quarter of 1946 until the third quarter of 1952 . In 1952, the tank was sluiced to a sludge heel to recover uranium from the metal waste. From the third quarter of 1953 until the first quarter of 1954, tank C-102 received uranium recovery waste. During the second quarter of 1957, the waste in tank $\mathrm{C}-102$ was scavenged and pumped out of the tank. From the third quarter of 1960 unti 1 the fourth quarter of 1969, tank C-102 received PUREX cladding waste, waste water, thorium high-level waste, and PUREX organic wash waste (Agnew et al. 1996).

The tank is sound and was removed from service in 1976 and declared inactive in 1977. Tank C-102 is passively ventilated. Tank C-102 was partially isolated in December 1982 and interim stabilized in September 1995 (Hanlon 1995).

This tank currently has a total waste volume of $1,196 \mathrm{~kL}$ (316 kgal), which is equivalent to $280 \mathrm{~cm}$ (110 in) of waste as measured from the baseline of the tank (Hanlon 1996).

This tank is on the Organic Watch List.

Near-term sampling and analysis activities are focused on either verifying or changing the Watch List tank status, and identifying any new safety issues. Should any other safety issues be identified, additional analysis will occur consistent with the identified issue.

In addition to the resolution of the safety issues, it is intended that all tank waste will be subject to pretreatment and retrieval to prepare for final storage or disposal. Presently, these long-range plans have yet to be fully identified and are, therefore, not included in this document. 
WHC-SD-WM-TP-206, REV 2

\subsection{PROGRAM ELENENTS REQUIRING INFORMATION FOR TANK 241-C-102}

This section identifies the various program elements, and identifies which of these programs require characterization data from tank C-102.

\subsection{GENERAL SAFETY ISSUES}

The Tank Safety Screening Data Quality Objective (Dukelow et al. 1995) describes the sampling and analytical requirements that are used to screen waste tanks for unidentified safety issues. Analytical requirements for the safety screening of a tank are energetics, total alpha activity, moisture content, density and flammable gas concentration.

\subsection{SPECIFIC SAFETY ISSUES}

\subsubsection{Ferrocyanide}

This tank is not on the Ferrocyanide Watch List; therefore, no information needs are currently identified for this program element.

\subsubsection{Organic}

This tank is on the Organic Watch List. Sampling and analysis requirements must be performed per the Data Quality Objective to Support Resolution of the Organic Complexant Safety Issue (Turner et al. 1995). The analyses employed will determine the total organic carbon (TOC), energetics, presence of a free organic liquid phase, and moisture content.

\subsubsection{High Heat}

This tank is not on the High Heat Watch List; therefore, no information needs are currently identified for this program element.

\subsubsection{Flammable Gas}

This tank is not on the Flammable Gas Watch List; therefore, no information needs are currently identified for this program element.

\subsubsection{Vapor}

All 177 underground tanks must be vapor sampled for organic solvent screening, per Recommendation 93-5 Implementation Plan (DOE-RL 1996). Some tanks may require additional vapor sampling due to other program needs. These tanks may be classified into four categories: (1) those tanks which are to be rotary mode core sampled (as a consequence of the rotary mode core sampling system exhauster permit requirements); (2) tanks on the Organic or Ferrocyanide Watch Lists; (3) tanks in C. farm; and (4) tank 24l-BX-104 due to vapor exposure. Information needs must satisfy Data Quality Objectives for Tank Hazardous Vapor Safety Screening (Osborne and Buckley 1995) and for rotary mode only, Rotary Core 


\section{WHC-SD-WM-TP-206, REV 2}

Vapor Sampling Data Quality Objective (Price 1994) and Data Quality Objective for Regulatory Requirements for Hazardous and Radioactive Air Emissions Sampling and Analysis (Mulkey and Markillie 1995) as amended by Status of the Current Understanding of the Toxic Air Pollutants (TAPS) and Hanford Tank Farm Vapor Space Characterization; Recommended Path Forward and Just ification for Cont inued RMCS Exhauster Operations (Laws 1996). (1994).

Tank C-102 was vapor sampled in August 1994 in support of Osborne et al.

\subsubsection{Criticality}

No information separate from that for the general safety issue of tank $c-102$ are currently identified for this program element. However, if the general safety screening of tank $\mathrm{C}-102$ identifies a potential criticality concern, analyses for fissile materials and neutron absorbers and poisons will be performed as identified in the safety screening data quality objective (DQO).

\subsection{CONTINUING OPERATIONS}

\subsubsection{Compatibility/Stabilization}

This section does not apply to tank C-102.

\subsubsection{Evaporator}

This section does not apply to tank $C-102$.

\subsection{DOUBLE-SHELL TANK WASTE ANALYSIS PLAN}

This section does not apply because tank $C-102$ is a single-shell tank.

\subsection{DISPOSAL}

\subsubsection{Retrieval}

Current retrieval needs (Bloom and Nguyen 1995) do not call for test samples to be taken from tank $\mathrm{C}-102$.

\subsubsection{Pretreatment/Vitrification}

Tank C-102 has not been identified as a bounding tank for pretreatment/ disposal process development strategy (Kupfer et al. 1995). All tanks were prioritized using the pretreatment strategy in the Tank Waste Characterization Basis (Brown et al. 1995) document and a portion of archive sample material could be used for pretreatment testing if available. The Strategy does not require any specific analyses to be done on the samples. 


\subsection{HISTORICAL MODEL EVALUATION}

This tank is identified as an acceptable alternative for the spatially complex tank 24l-B-104 (B-104) in Historical Model Evaluation Data Requirements (Simpson and McCain 1995). The applicability of these analyses will be determined based on tank B-104's sampling and analys is and will be documented in the tank specific sample and analysis plan.

\subsection{HOW INFORMATION WILL BE OBTAINED}

The number of samples required to characterize a tank is a function of waste heterogeneity and the desired confidence to make a correct decision. As directed by the safety screening $\mathrm{DQO}$, if inadequate information exists to determine an appropriate number of samples, two vertical profiles will be obtained. These vertical profiles may be obtained using core, auger (for shallow tanks), or grab samples. If analysis of these profiles reveals that additional profiles are necessary to meet data needs, more sample profiles will be requested. Prior to rotary sampling it is necessary to vapor sample the tank per the requirements of Rotary Core Vapor Sampling Data Quality Objective (Price 1994).

\subsection{PRIORITY OF INFORMATION REQUIREMENTS}

Vapor sampling was completed in August 1994. Auger sampling was completed in January 1995. Rotary mode core sampling is scheduled to begin in April 1997 (Stanton 1996). Refer to Table 4-1 for the current DQO requirements and planned sampling and analytical requirements.

Table 4-1: Integrated DQO Requirements and Priorities

\begin{tabular}{||l|l|l|l|}
\hline $\begin{array}{l}\text { Sampling } \\
\text { Event }\end{array}$ & \multicolumn{1}{|c|}{ Applicable Issues } & Sampling Requirements & Analytical Requirements \\
\hline $\begin{array}{l}\text { Vapor } \\
\text { Sampling }\end{array}$ & $\begin{array}{l}\text {-Organic Solvent Layer } \\
\text { 93-5 Vapor Issue } \\
\text {-Rotary Mode Sampl ing } \\
\text { DQO } \\
\text {-Hazardous Vapor DQO }\end{array}$ & $\begin{array}{l}\text { Steel canisters, } \\
\text { Triple Sorbent Traps, } \\
\text { Sorbent Trap Systems }\end{array}$ & $\begin{array}{l}\text { Flammable Gas } \\
\text { Organic Vapors } \\
\text { Permanent Gases }\end{array}$ \\
\hline $\begin{array}{l}\text { Rotary } \\
\text { Mode Core } \\
\text { Sampling }\end{array}$ & $\begin{array}{l}\text {-Safety Screening DQO } \\
\text {-Organic DQO }\end{array}$ & $\begin{array}{l}\text { Core samples from a } \\
\text { minimum of 2 risers } \\
\text { separated radially to } \\
\text { the maximum extent } \\
\text { possible } \\
\text { Combustible gas } \\
\text { measurement }\end{array}$ & $\begin{array}{l}\text { Flammability, Energetics, } \\
\text { Moisture, Total alpha } \\
\text { activity, TOC, Density, } \\
\text { Separable Organics }\end{array}$ \\
\hline
\end{tabular}

* Consult each applicable $\mathrm{DQO}$ in force at the time for sampling and analytical requirements. 


\section{WHC-SD-WM-TP-206, REV 2}

\subsection{WHEN INFORMATION WILL BE AVAILABLE}

According to Stanton (1996), data are expected to be available from the rotary mode core sampling event in August 1997. This time may be altered if the sampling schedule changes. Data are available from the August 1994 vapor sampling and the January 1995 auger sampling.

\subsection{REFERENCES}

Agnew, S. F., R. A. Corbin, T. B. Duran, K. A. Jurgensen, T. P. Ortiz, and B. L. Young, 1996, Waste Status and Transaction Record Summary for the Northeast Quadrant of the Hanford 200 Area, WHC-SD-WM-TI-615, Rev. 1, Westinghouse Hanford Company, Richland, Washington.

Bloom, G. R. and Q. H. Nguyen, 1995, Characterization Data Needs for Development, Design and Operation of Retrieval Equipment Developed Through the Data Quality 0bjective Process, WHC-SD-WM-DQ0-008, Rev. 0, Westinghouse Hanford Company, Richland, Washington.

Brevick, C. H., L. A. Gaddis, and W. W. Pickett, 1995, Historical Tank Content Estimate for the Northeast Quadrant of the Hanford 200 East Areas, WHC-SD-WM-ER-359, Rev. OA, Westinghouse Hanford Company, Richland, Washington.

Brown, T. M., S. J. Eberlein, and T. J. Kunthara, 1995, Tank Waste Characterization Basis, WHC-SD-WM-TA-164, Rev. 1, Westinghouse Hanford Company, Richland, Washington.

DOE-RL, 1996, Recommendation 93-5 Implementation Plan, DOE/RL-94-0001, Rev. 1, U.S. Department of Energy, Richland, Washington.

Dukelow, G. T., J. W. Hunt, H. Babad, and J. E. Meacham, 1995, Tank Safety Screening Data Quality Objective, WHC-SD-WM-SP-004, Rev. 2, Rich Tand, Washington.

Hanlon, B.M., 1995, Waste Tank Summary for Month Ending September 30, 1996, WHC-EP-0182-90, Westinghouse Hanford Company, Richland, Washington.

Hanlon, B.M., 1996, Waste Tank Summary for Month Ending January 31, 1996, WHC-EP-0182-94, Westinghouse Hanford Company, Richland, Washington.

Kupfer, M. J., W. W. Schultz, and J. T. Slankas, 1995, Strategy for Sampling Hanford Site Tank Wastes for Development of Disposal Technology, WHC-SD-WM-TA-154, Rev. 1, Westinghouse Hanford Company, Richland, Washington. 


\section{WHC-SD-WM-TP-206, REV 2}

Laws, G. L., 1996, Status of the Current Understanding of the Toxic Air Pollutants (TAPS) and Hanford Tank Farm Vapor Space Characterization; Recommended Path Forward and Justification for Continued RMCS Exhauster Operations, (telephone conference memorandum 01830-96-022, to Distribution, March 8), Westinghouse Hanford Company, Richland, Washington.

Mulkey, C. H., and K. D. Markillie, 1995, Data Quality Objective for Regulatory Requirements for Hazardous and Radioactive Air Emissions Sampling and Analysis, WHC-SD-WM-DQO-021, Rev. 0, Westinghouse Hanford Company, Richland, Washington.

Osborne, J. W., J. L. Huckaby, E. R. Hewitt, C. M. Anderson, D. D. Mahlum, B. A. Pulsipher, and J. L. Young, 1994, Data Quality Objectives for Generic In-Tank Health and Safety Vapor Issue Resolution, WHC-SD-WM-DQO002, Rev. 0, Westinghouse Hanford Company, Richland, Washington.

Osborne, J. W., and L. L. Buckley, 1995, Data Quality Objectives for Tank Hazardous Vapor Safety Screening, WHC-SD-WM-0Q0-002, Rev. 2, Westinghouse Hanford Company, Richland, Washington.

Price, D. N., 1994, Rotary Core Vapor Sampling Data Quality Objective, WHC-SD-WM-SP-003, Rev. 0, Westinghouse Hanford Company, Richland, Washington.

Simpson, B. C., and D. J. McCain, 1995, Historical Model Evaluation Data Requirements, WHC-SD-WM-DQ0-018, Rev. OA, Westinghouse Hanford Company, Richland, Washington.

Stanton, G. A., 1996, Baseline Sampling Schedule, Change 96-02, (internal memo 75610-96-06, to Distribution, Aprij 17), Westinghouse Hanford Company, Richland, Washington.

Turner, D. A., H. Babad, L. L. Buckley and J. E. Meacham, 1995, Data Quality Objective to Support Resolution of the Organic Complexant Safety Issue, WHC-SD-WM-DQ0-006, Rev. 2, Westinghouse Hanford Company, Richland, Washington. 


\section{DISTRIBUTION SHEET}

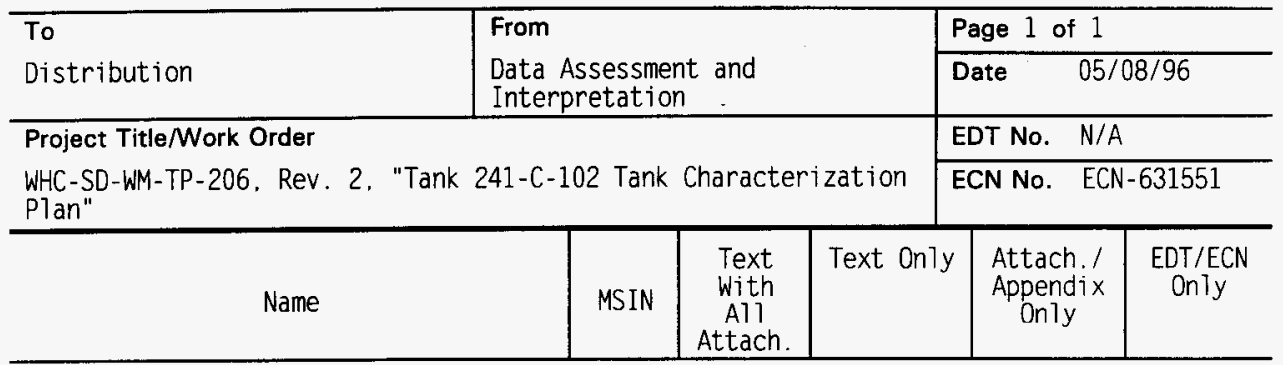

\section{ONSITE}

U. S. Department of Energy -

Richland Field office

W. Liou

N. W. Willis

Westinghouse Hanford Company

G. D. Forehand

C. S. Homi

L. M. Sasaki

Central Files

T.C.R.C. $\begin{array}{ll}\text { S7 }-54 & x \\ \text { S7 }-54 & x\end{array}$

\section{OFFSITE}

U. S. Department of Enerqy - Headquarters

Office of Environmental Restoration and Waste Management EM-563

12800 Middlebrook Road

Germantown. MD 20874

J. A. Poppiti

$\begin{array}{ll}\text { S7 }-21 & \text { X } \\ \text { R2 }-12 & x \\ \text { R2-12 } & x \\ \text { A3-88 } & x \\ \text { R2-12 } & X\end{array}$

